\title{
China's Tourism-Led Foreign Direct Investment Inflows: An Empirical Study
}

\author{
Yawen Chen \\ Jinan University, Guangzhou, China \\ Email: 1012809927@qq.com
}

How to cite this paper: Chen, Y.W. (2017) China's Tourism-Led Foreign Direct Investment Inflows: An Empirical Study. Modern Economy, 8, 39-50.

http://dx.doi.org/10.4236/me.2017.81004

Received: December 21, 2016

Accepted: January 10, 2017

Published: January 13, 2017

Copyright $\odot 2017$ by author and Scientific Research Publishing Inc. This work is licensed under the Creative Commons Attribution International License (CC BY 4.0).

http://creativecommons.org/licenses/by/4.0/

\begin{abstract}
Based on the annual data of China from 2000 to 2014, this paper applies the dynamic panel model to study the relationship between inbound tourism and foreign direct investment (FDI). Compared with previous literatures, our analysis is not limited to the study of FDI in single tourism sectors such as hotels and restaurants, but takes general FDI into consideration. The empirical results show that the growth of inbound tourism can not only promote FDI flow into the tourism industries, but also increase the inflows of FDI to other sectors. In other words, the flourished inbound tourism may have spillover impacts of FDI on non-tourism sectors. It's also indicated that the two policies of inbound tourism improvement and inward FDI promotion are complementary. Therefore, I believe coordination can maximize the effect of policies, because the two policies may coordinate with each other to achieve economic growth targets.
\end{abstract}

\section{Keywords}

Inward FDI, Inbound Tourism, Tourism Enhancement, FDI Promotion

\section{Introduction}

With various countries slowing down the pace of economic development, China's economy has shown a new normal. Li Jinzao, the director of the National Tourism Administration, said that the new normal was to improve the quality and enhance the efficiency, that is, to adjust development speed but not diminish momentum, and to attain better quality as well as high quantity. In order to achieve a comprehensive coordination of speed, quality and efficiency, the stock adjustment and increment optimization must be combined, so that economy can shift from traditional growth point to a new one. Under the new normal, exploring and nurturing new growth pole will be the key of promoting sustainable 
development of economic society. Moreover, the tourism industry is becoming a new engine of economic growth under the new normal. In this context, promoting the development of tourism industry, which is called "sunrise industry", is particularly important. However, the enhancement of China's tourism is in great need of financial support that mainly comes from government funds, domestic capital and inward FDI. Due to the relative lack of domestic funds, it's imminent to speed up the introduction of foreign capital. Among factors influencing the foreign capital into the tourism industry, the number of arrivals and foreign earnings are the most critical indicators [1]. Inbound tourism facilitate not only export revenue generation but also service sector job creation through tourism-related FDI, however, has shown signs of weakness in recent years. Thus, in order to flourish inbound tourism, we must first make clear what kind of relationship between inbound tourism and FDI is and whether the inward FDI only flows to the tourism-related industries, then formulates a more effective policy according to the degree of correlation.

Since the publication of the United Nations Conference on Trade and Development (UNCTAD) (2007) report, more and more articles have discussed this issue, but the current literature is inadequate. The primary focus in the literature is the relationship between tourism and tourism-related FDI. In fact, the development of inbound tourism will not only attract more FDI into tourism-related sectors (such as hotels, airlines and restaurants), but also indirectly promote the FDI inflows into other sectors. Thus, this paper will start from the spillover effect of tourism development on FDI to explore the relationship between inbound tourism and inward FDI by applying dynamic panel models. The conclusion reveals that enhanced international tourism may achieve economic growth targets through increased FDI inflows into tourism-related and non-tourism industries.

The reminder of this paper is organized as follows. Section 2 briefly introduces the domestic and foreign literatures. Section 3 presents a description of data and model used for analysis. Section 4 explains the empirical results. Section 5 gives conclusions and policy recommendation.

\section{Review of Domestic and Foreign Literatures}

As Premier Li Keqiang said at the opening of the BOAO Forum for Asia, the tourism is not only a service industry, but a comprehensive one, covering the primary industry, secondary industry and tertiary industry. In addition, inbound tourism can create foreign exchange and employment for a country. Despite the fact that both FDI and tourism play important roles, the research on the relationship between tourism and FDI in host country is inadequate. As is shown in the literatures at home and abroad, the existing studies mainly focus on the relationship between tourism and FDI from three perspectives. One is from the perspective of tourism industry, usually in the VAR or VECM theory framework, using Ranger Causality method to test the relationship. Conclusions suggest the long-term existence of bilateral equilibrium and the two-way causality [2] [3] [4] [5] [6]. These papers only focusing on tourism-related sector FDI 
(such as hotels, restaurants, transportation, etc.), but do not cover general FDI. Secondly, some consider the FDI inflows into China's tourism from view of policy. The results show that the rapid development of China's tourism can promote FDI into the domestic tourism sectors, but these studies are restricted to qualitative analysis, not exploring the causal relationship [7] [8]. Thirdly, in the view of the spillover effects of international tourism on FDI, Akinori Tomohara, based on the relevant data of Japan, expounded this problem [9]. Yet there is still a lack of systematic research on the relationship between China's inbound tourism and inward FDI.

After briefly reviewing the literatures, we can find the existing researches are mostly based on qualitative or simple regression to examine the causality between tourism development and tourism-related FDI using time-series analysis. There is no empirical analysis about the correlation of the two variables, let alone consider it from view of the spillover effects.

Therefore, we focus on the spillover effects of tourism development on FDI to explore the interaction between inbound tourism and inward FDI. The innovations of this paper are as follows. On the part of data, this study uses a sample of 23 countries/areas, each of which is a major FDI donor to China over the period of 2000-2014. We use panel data not yet time-series analysis. When it comes to the inbound tourism-inward FDI relationships, we draw our attention to the positive spillover effects of tourism development on FDI in non-tourism sectors, not limited to the discussion about typical tourism-related FDI. Moreover, to avoid the pseudo-regression, we choose a two-step difference generalized method of moments (GMM). This paper also uses EXCEL to deal with data and Eviews8.0 to conduct dynamic panel regression.

\section{Model and Data}

FDI has been long regarded as the engine of development, and in recent years, enhanced tourism is expected to contribute to local economic rival. Thus, it's necessary to figure out whether expanded inbound tourism mainly increases inward FDI in tourism-related sectors. However, it seems not the case, because the level of FDI inflows into tourism-related industry is not large compared to the total inward FDI in China. Rather, major recipients of inward FDI in China are sectors such as manufacturing, real estate, leasing and business services, electricity, gas and water supply, agriculture, forestry, animal husbandry and fisheries, not the tourism sector. Hence, it's meaningful to figure out whether tourism influences FDI in non-tourism sectors.

We use major FDI donor countries (regions) to China as our sample, which are also major source countries (regions). In 2014, for example, the top ten FDI donor countries (regions) to China (Hong Kong, Singapore, Taiwan, The United States, Germany, The United Kingdom, France and Netherlands) contributed a total of US $\$ 112.59$ billion, accounting for $94.2 \%$ of China's actually used foreign capital. In view of the facts and data availability, the sample comprises 23 countries/areas from Asia (Hong Kong, Taiwan, Japan, South Korea, Singapore, 
Thailand, India, Indonesia, Malaysia and Philippines), North America (The United States and Canada), Pacific (Australia and New Zealand), Europe (The United Kingdom, Germany, France, Italy, Netherlands, Portuguesa, Sweden, Switzerland and Russia). Mauritius and Samoa, two major FDI donors, are not included in our sample because the State Statistical Bureau does not provide any records of tourists from Mauritius and Samoa.

We set up our model by extending the framework of FDI determination to a dynamic context. In this model, FDI depends on the initial FDI and the arrivals. Meanwhile, other factors determining FDI are controlled, whereas previous studies focused on causal relationship between tourism and tourism-related FDI (Katircioglu, 2011; Samimi, et al. 2013; Selvanathan, et al. 2012; Tang, et al. 2007 for China) [2] [3] [4] [5]. As is shown in the following conceptual framework, FDI is a function of Tour and control variables (X), that is, FDI $=\mathrm{f}$ (Tour, $\mathrm{X}$ ). Since the general FDI consists of tourism-related industries FDI and non-tourism sectors FDI, the studies mentioned above may underestimate the spillover effects of inbound tourism, without taking non-tourism sectors FDI into consideration. To avoid the pseudo-regression, we use a two-step GMM (Arellano and Bover, 1995; Blundell and Bond, 1998; Wind Meijer, 2005) to study the FDI dynamics [10] [11] [12]. The difference GMM can eliminate the simultaneous bias between the net inflow of FDI and the number of inbound tourists. FDI, Tourists and GDP are regarded as endogenous variables in the actual estimation of the FDI determination equation. It's not easy for us to pick out appropriate instrumental variables to solve the endogenous problem, but difference GMM enables us to make it. In this paper, the endogenous variables lagged by two or three periods are used as the instrumental variables for difference equations.

$$
\mathrm{FDI}_{i t}=\alpha+\beta_{1} \mathrm{FDI}_{i t-1}+\beta_{2} \text { Tour }_{i t}+X_{i t} \rho+\varepsilon_{i t}, \varepsilon_{i t}=\delta_{i t}+\mu_{i t}
$$

As is shown in the Equation (1), $\mathrm{FDI}_{i t}$ denotes the net inflow of FDI from country $i$ to China at time $t$, Tour ${ }_{i t}$ represents the number of inbound tourists, $X_{i t}$ is a set of control variables, and $\varepsilon_{i t}$ is an error term that consists of $\delta_{i t}$ and $\mu_{i t}$

Table 1 summarizes the description of variables used for the analysis, along with their data sources. These variables, based on 2000-2014 Chinese data, are chosen by referring to Blonigen and Piger (2011) and Eicher, et al. (2012) [13]. In our analysis, GDP, Corruption, Fair Competition and EPA are regarded as the control variables. GDP represents the market size of the source country (region), the greater the market size, the more FDI flows into China. An Economic Partnership Agreement (EPA) is expected to promote cross-border factor flow. When the Agreement comes into effect, more inward FDI will come into China. EPA takes the value of 1 if it's effective for more than five months in the year under consideration and 0 otherwise. The dummy is adjusted to zero for Hong Kong (effective September 2003), Singapore (effective October 2008). EPA includes Free Trade Agreement (FTA), as well as Economic Cooperation Framework Agreement (ECFA), and Closer Economic Partnership Arrangement (CEPA). The corruption and fair competition terms draw attractiveness for in- 
vestment to China. The more inefficient the source country (region), the more FDI will flow into our country. The fairer registration for a foreign company, the host country will lure more foreign capital. Table 2 presents the sample's summary statistics.

Table 1. Description of variables with data sources.

\begin{tabular}{|c|c|c|}
\hline Variables & Sources & Description \\
\hline Inward FDI & State Statistical Bureau & $\begin{array}{l}\text { The FDI data include sub-national } \\
\text { (sub-regional) and sub-sector data. }\end{array}$ \\
\hline Tourists & $\begin{array}{l}\text { Annual report on } \\
\text { Tourism Statistics }\end{array}$ & $\begin{array}{l}\text { Tourists include foreigners and Hong Kong, } \\
\text { Macao and Taiwan compatriots. }\end{array}$ \\
\hline GDP & $\begin{array}{l}\text { World Development } \\
\text { Indicators (WDI) }\end{array}$ & GDP (current US \$). \\
\hline Corruption & $\begin{array}{l}\text { The Worldwide } \\
\text { Governance Indicators }\end{array}$ & $\begin{array}{l}\text { An evaluation of governance performance for a } \\
\text { host country during } 2000-2014 \text {, except for the } \\
\text { years } 2001 \text { and indicators range from }-2.5 \\
\text { (weak) to } 2.5 \text { (strong). }\end{array}$ \\
\hline $\begin{array}{c}\text { Fair } \\
\text { Competition }\end{array}$ & $\begin{array}{c}\text { The IMD World } \\
\text { Competitiveness Yearbook }\end{array}$ & $\begin{array}{l}\text { An evaluation of whether "competition } \\
\text { legislation is efficient on preventing unfair } \\
\text { competition" and indicators range from } 0 \text { to } 10 \text {. }\end{array}$ \\
\hline EPA Dummy & $\begin{array}{l}\text { China Free Trade Area } \\
\text { Service Network }\end{array}$ & $\begin{array}{l}\text { EPA takes the value of } 1 \text { if it's effective for } \\
\text { more than five months in the year under } \\
\text { consideration and } 0 \text { otherwise. }\end{array}$ \\
\hline Per capita GDP & $\begin{array}{l}\text { World Development } \\
\text { Indicators (WDI) }\end{array}$ & Per capita GDP (current US \$). \\
\hline $\begin{array}{c}\text { Taiwan } \\
\text { Information }\end{array}$ & $\begin{array}{c}\text { ROC Statistical } \\
\text { Information Network }\end{array}$ & GDP \& Per capita GDP (current US \$). \\
\hline
\end{tabular}

Table 2. Summary statistics.

\begin{tabular}{|c|c|c|c|c|c|}
\hline Variables & $\begin{array}{c}\text { Units of } \\
\text { measurement }\end{array}$ & Mean & $\begin{array}{l}\text { Standard } \\
\text { deviation }\end{array}$ & Maximum & Minimum \\
\hline Inward FDI & Current million US \$ & 2836.349 & 9668.668 & 81268.20 & 0.480000 \\
\hline Tourists & Ten thousand & 409.6982 & 1472.383 & 7935.700 & 2.280000 \\
\hline GDP & Current million US \$ & $1,674,595$ & $2,926,363$ & $17,419,000$ & 52623.10 \\
\hline Corruption & $\begin{array}{l}\text { Indicators range from } \\
-2.5 \text { to } 2.5\end{array}$ & 1.183634 & 0.786548 & 2.430000 & -0.770000 \\
\hline Fair Competition & $\begin{array}{l}\text { Indicators range from } \\
0 \text { to } 10\end{array}$ & 6.424969 & 0.939051 & 8.310000 & 4.140000 \\
\hline EPA & $\begin{array}{l}1 \text { for EPA taking effect } \\
\text { and } 0 \text { otherwise }\end{array}$ & 0.093168 & 0.291120 & 1.000000 & 0.000000 \\
\hline GDP Sum & Current million US \$ & $6,141,160$ & $4,436,443$ & $27,773,832$ & $1,257,884$ \\
\hline GDP Diff Squared & Current million US \$ & $2.39 \mathrm{E}+13$ & $3.06 \mathrm{E}+13$ & $1.24 \mathrm{E}+14$ & $5.89 \mathrm{E}+08$ \\
\hline Factor Diff & Current million US \$ & 25027.83 & 18687.68 & 82428.42 & -6008.510 \\
\hline $\begin{array}{l}\text { GDP Diff } \\
{ }^{*} \text { Factor Diff }\end{array}$ & Current million US \$ & $-6.98 \mathrm{E}+10$ & $1.66 \mathrm{E}+11$ & $4.97 \mathrm{E}+11$ & $-7.53 \mathrm{E}+11$ \\
\hline
\end{tabular}

Note: GDP diff is used as a proxy for differences in GDP between a source country and a host country. Factor diff stands for differences in relative factor endowments in the two countries. 


\section{Empirical Research}

\subsection{Panel Unit Root Test \& Co-Integration Test}

In order to avoid suspicious results, we employ LLC (Levin-Lin-Chu) test to examine whether these variables are stable. The results are shown in Table 3.

At the 5\% significance level, all variables were stable except for FDI and fair competition. After further examination of the first-order difference, all variables were stable at the $1 \%$ significance level, which means that all variables are I (1). We use Pedroni Test to examine heterogeneous panel data and model. The Pedroni Test is actually a left-tail test of statistical indicator. If it's turned out to be less than -1.96 , then we can reject the null hypothesis that there is no co-integration between the variables. Hence, we can find from Table 4 that co-integration is shown in the Equation (1).

\subsection{Results and Explanations}

The regression results for Equation (1) are shown in Table 5. For each variable, the first row stands for the estimated coefficients and the second row indicates the standard error in parentheses. Column 1 demonstrates the results obtained with all control variables. As the regression coefficient sign is contrary to expectation, we conduct the estimation without the variable (Column 2). All variables are statistically significant and in line with economic expectations. The greater the market size of source country (region), the more FDI flows into China. The more inefficient the source country (region), more FDI will flow into our country. The more fair registration for a foreign company, the host country will lure more foreign capital.

The results suggest that inbound tourism has synergy with inward FDI. The coefficient on inbound tourists is turned out to be positive and statistically significant. As is shown in Column (2), every ten thousand visitors to China will attract $\$ 5.42$ million FDI inflows. When sharing similar policy objectives, a beneficial interaction between inbound tourism and inward FDI is found. The improvement of inbound tourism enlarges the effectiveness of FDI promotion.

Table 3. Panel unit root test.

\begin{tabular}{ccc}
\hline Variable & LLC Statistic & Result \\
\hline Inward FDI & -0.73402 & unstable \\
Tourists & $-4.45539^{* * *}$ & stable \\
GDP & $-1.79978^{* *}$ & stable \\
Corruption & $-2.30570^{* *}$ & stable \\
Fair competition & -1.11622 & unstable \\
$\Delta$ FDI & $-5.79092^{* * *}$ & stable \\
$\Delta$ Tourists & $8.43146^{* *}$ & stable \\
$\Delta$ GDP & $9.29000^{* * *}$ & stable \\
$\Delta$ Corruption & $-13.2120^{* * *}$ & stable \\
$\Delta$ Fair competition & $-3.16705^{* * *}$ & stable \\
\hline
\end{tabular}

Note: ${ }^{* * *}$ Denotes coefficient significance at $1 \%$ level. ${ }^{* *}$ Denotes coefficient significance at $5 \%$ level. 
Table 4. Co-integration test.

\begin{tabular}{ccc}
\hline Pedroni Test & Statistic & Result \\
\hline Panel-PP & $-3.432965^{* * *}$ & co-integration \\
Panel-ADF & $-2.291997^{* *}$ & co-integration \\
Group-PP & $-5.786787^{* * *}$ & co-integration \\
\hline
\end{tabular}

Note: ${ }^{* *}$ Denotes coefficient significance at $1 \%$ level. ${ }^{* *}$ Denotes coefficient significance at $5 \%$ level.

Table 5. Results of inbound tourism effects in Benchmark.

\begin{tabular}{ccc}
\hline Variable & $(1)$ & $(2)$ \\
\hline L1. Inward FDI & 0.933662 & 0.935110 \\
Tourists & $(0.003399)^{* * *}$ & $(0.002629)^{* * *}$ \\
& 5.896787 & 5.454510 \\
GDP & $(0.060697)^{* * *}$ & $(0.029855)^{* * *}$ \\
& 0.000533 & 0.000318 \\
Fair competition & $(5.29 \mathrm{E}-05)^{* * *}$ & $(4.33 \mathrm{E}-05)^{* * *}$ \\
& -132.8082 & -213.4359 \\
Corruption & $(16.01520)^{* * *}$ & $(2.428945)^{* * *}$ \\
& -2547.210 & -2723.124 \\
EPA & $(59.86042)^{* * *}$ & $(33.36720)^{* * *}$ \\
AR(1) & -1241.959 & \\
AR(2) & $(50.67664)^{* * *}$ & 0.2556 \\
Sargan statistic & 0.4671 & 0.3456 \\
No. of observation & 0.5536 & 0.6970 \\
\hline
\end{tabular}

Note: The first- and second-order correlation Arellano-Bond (AB) tests have $p$-values greater than $10 \%$, which means that there is not enough evidence to support that there is autocorrelation. Additionally, the $p$-values of the Sargan test of over-identifying restrictions fails to reject the null hypothesis that the instruments are exogenous in any specification. ${ }^{* * *}$ Denotes coefficient significance at $1 \%$ level.

It has been demonstrated above that the enhancement of inbound tourism will lure more foreign capital to China. It would be of interest to know whether most effects of inbound tourism on inward FDI are explained by the expanded FDI in tourism-related industries. Indeed, compared to the total FDI inflows to China, there is not so much FDI flowing into tourism-related sectors (such as transportation and services). According to the National Bureau of Statistics (NBS), the main recipients of inward FDI in China are sectors such as manufacturing, real estate, leasing and business services, electricity, gas and water supply and agriculture, forestry, animal husbandry and fishery. This means that a large part of FDI flows to non-tourism sectors in China. Thus, we make a further examination to verify that tourism impacts FDI on non-tourism sectors.

We use data on inward FDI by country and industry to support our assertion. In accordance with the Tourism Satellite Account (TSA), tourism has been divided into the following 13 categories. That is, wholesale and retail, catering, hotels, ground transportation, waterway transportation, air transport and other 
passenger transport, other financial services, other business/technical services, government services, media/entertainment services, other recreational services, personal/domestic services. Given the availability of data, we define the culture, sport and entertainment, wholesale and retail, transportation, warehousing and postal services, accommodation and catering industries as the tourism-related industries. According to the National Bureau of Statistics (NBS), the data on inward FDI by industry are available only from the year 2004. During 2004-2014, the FDI absorbed by the tourism-related sectors accounted for $5.44 \%, 6.16 \%$, $7.69 \%, 8.26 \%, 9.18 \%, 10.08 \%, 9.66 \%, 11.29 \%, 14.73 \%$ and $12.88 \%$. Referring to Akinori Tomohara, we figure out the amount of tourism-related inward FDI by source country (region) in 2004-2014. When tourism-related inward FDI replaces total inward FDI in Equation (1), the results are shown in column labeled as tourism-related FDI. The column labeled as total FDI replicates the analysis of total FDI under our benchmark model during the period 2004-2014.

As is shown in Table 6, the coefficient of tourists is turned out to be positive and statistically significant in both columns. Moreover, the effects of tourism on total FDI are estimated to be 7.5 times as large as those on tourism-related FDI. This suggests that the increase of inbound tourists will promote FDI inflow into China. It also confirms our hypothesis that the enhancement of inbound tourism may have positive spillovers on inward FDI beyond tourism-related industries. The large effect includes not only the direct spillover effects in tourism-related sectors but also indirect effects in non-tourism industries. In other words, with a

Table 6. Spillover effects of inbound tourism.

\begin{tabular}{ccc}
\hline Variable & Tourism-related FDI & Total FDI \\
\hline L1. Inward FDI & 0.954264 & 0.901557 \\
Tourists & $(0.002146)^{* * *}$ & $(0.001670)^{* * *}$ \\
& 1.842374 & 13.82422 \\
GDP & $(0.012338)^{* * *}$ & $(0.051571)^{* * *}$ \\
& $-5.08 \mathrm{E}-05$ & 0.000737 \\
Fair competition & $(7.73 \mathrm{E}-06)^{* * *}$ & $(2.99 \mathrm{E}-05)^{* * *}$ \\
& 27.33449 & -1059.483 \\
Corruption & $(2.857150)^{* * *}$ & $(11.78894)^{* * *}$ \\
& -1635.425 & -3769.372 \\
EPA & $(16.46278)^{* * *}$ & $(261.0455)^{* * *}$ \\
AR(1) & 226.2965 & 137.1918 \\
AR(2) & $(34.39553)^{* * *}$ & $(59.91870)^{* *}$ \\
Sargan statistic & 0.3059 & 0.2204 \\
No. of observation & 0.3702 & 0.4064 \\
\hline
\end{tabular}

Note: The first- and second-order correlation Arellano-Bond (AB) tests have $p$-values greater than $10 \%$, which means that there is not enough evidence to support that there is autocorrelation. Additionally, the $p$-values of the Sargan test of over-identifying restrictions fails to reject the null hypothesis that the instruments are exogenous in any specification. ${ }^{* * *}$ Denotes coefficient significance at $1 \%$ level. ${ }^{* *}$ Denotes coefficient significance at 5\% level. 
growing number of arrivals from a source country (region), the increased FDI may flow into non-tourism industries. This also implies that the two policies of inbound tourism improvement and inward FDI promotion are complementary.

\subsection{Robustness Test}

We want to make clear whether the correlation between inbound tourism and inward FDI only exist in Equation (1). Thus, we attempt to test whether the empirical results would vary with different parameters by using different specifications of economic theories. Referring to Blonigen and Piger (2011), Eicher, et al. (2012), we find that some other scholars used the knowledge capital model to study the determinants of FDI. In accordance with Akinori Tomohara, we explore the effects of inbound tourism in the context of the knowledge capital model, where both vertical and horizontal FDI arise (Markusen, 1997; Markusen, et al. 1996) [14] [15]. Replace GDP with GDP sum, GDP diff squared, Factor diff and GDP diff ${ }^{\star}$ Factor diff to verify the conclusion mentioned above. We introduce FDI dynamics, together with tourism effects, into Carr, et al. (2001, 2003) [16] [17], which is shown as follows.

$$
\begin{aligned}
\mathrm{FDI}_{i t} & =\alpha+\beta_{1} \mathrm{FDI}_{i t-1}+\beta_{2}\left(\mathrm{GDP}_{i t}+\mathrm{GDP}_{j t}\right)+\beta_{3}\left(\mathrm{GDP}_{i t}-\mathrm{GDP}_{j t}\right)^{2} \\
& +\beta_{4}\left(\text { Factor }_{i t}-\text { Factor }_{j t}\right)+\beta_{5}\left(\text { Factor }_{i t}-\text { Factor }_{j t}\right) *\left(\mathrm{GDP}_{i t}-\mathrm{GDP}_{j t}\right) \\
& +\beta_{6} \text { Tourists }_{i t}+X_{i t} \rho+\varepsilon_{i t}, \\
\varepsilon_{i t}= & \delta_{i t}+\mu_{i t}
\end{aligned}
$$

$\operatorname{GDP}_{i t}\left(\mathrm{GDP}_{j t}\right)$ stands for the GDP of a source country (region) $i$ (or a host country) at time $t$, Factor $_{i t}\left(\right.$ Factor $\left._{j t}\right)$ is the per capita GDP, and $X_{i t}$ is a set of control variables related to investment and trade costs. GDP sum represents the total market size of the source country (region) and host country, which has a positive pull for FDI. The square of the GDP difference reflects the size difference between the two countries (regions). When the difference is small, it will attract horizontal FDI, otherwise will lure vertical FDI. Differences in per capita GDP are used as a proxy for differences in relative factor endowments. Horizontal FDI increases with growing similarity in income and relative factor endowments between the source and host countries (regions). Vertical FDI, on the other hand, increases with the dissimilarity of factor endowments between the source and host countries (regions). GDP diff ${ }^{\star}$ Factor diff demonstrates the interaction of differences in factor endowments and economic size.

Results support a beneficial interaction between inbound tourism and inward FDI, as mentioned in the previous analysis. In other words, the enhancement of inbound tourism, indeed, has positive spillovers on inward FDI beyond tourism-related industries. We follow the analysis using difference GMM, where FDI, GDP-related terms, and inbound tourists are treated as endogenous. The endogenous variables lagged by two periods are used as instruments for difference equations. Overview from Table 7, the coefficient of tourists is turned out to be positive and statistically significant in both columns. What's more, the impacts of tourism on total FDI are estimated to be 7.18 times, which is 7.5 times in 
Table 7. Results of inbound tourism effects in Knowledge Capital.

\begin{tabular}{|c|c|c|}
\hline Variable & Tourism-related FDI & Total FDI \\
\hline \multirow{2}{*}{ L1. Inward FDI } & 0.911652 & 0.858631 \\
\hline & $(0.008720)^{\star * *}$ & $(0.004220)^{\star * *}$ \\
\hline \multirow{2}{*}{ Tourists } & 1.933043 & 13.88405 \\
\hline & $(0.018658)^{\star * *}$ & $(0.120658)^{\star * \star}$ \\
\hline \multirow{2}{*}{ GDP sum } & $-3.27 \mathrm{E}-05$ & $-9.32 \mathrm{E}-05$ \\
\hline & $(5.90 \mathrm{E}-06)^{* * *}$ & $(3.09 \mathrm{E}-05)$ \\
\hline \multirow{2}{*}{ GDP diff squared } & $1.53 \mathrm{E}-12$ & $8.56 \mathrm{E}-12$ \\
\hline & $(7.14 \mathrm{E}-13)^{\star \star}$ & $(2.66 \mathrm{E}-12)^{* * *}$ \\
\hline \multirow{2}{*}{ Factor diff } & -0.012516 & -0.003202 \\
\hline & $(0.003326)^{\star * \star}$ & $(0.014981)$ \\
\hline \multirow{2}{*}{ GDP $\operatorname{diff}^{\star}$ Factor diff } & $-1.70 \mathrm{E}-09$ & $-8.38 \mathrm{E}-09$ \\
\hline & $(2.06 \mathrm{E}-10)^{* * *}$ & $(1.45 \mathrm{E}-09)^{\star * *}$ \\
\hline \multirow{2}{*}{ Corruption } & -1875.754 & -6910.898 \\
\hline & $(41.43756)^{\star \star \star *}$ & $(129.6300)^{* * *}$ \\
\hline \multirow{2}{*}{ EPA } & 145.4945 & -177.6922 \\
\hline & $(40.48713)^{\star * \star}$ & $(112.2335)$ \\
\hline $\operatorname{AR}(1)$ & 0.1597 & NA \\
\hline $\operatorname{AR}(2)$ & 0.5158 & 0.4279 \\
\hline Sargan statistic & 0.6757 & 0.5077 \\
\hline No. of observation & 276 & 276 \\
\hline
\end{tabular}

Note: The first- and second-order correlation Arellano-Bond (AB) tests have $p$-values greater than $10 \%$, which means that there is not enough evidence to support that there is autocorrelation. Additionally, the $p$-values of the Sargan test of over-identifying restrictions fails to reject the null hypothesis that the instruments are exogenous in any specification. ${ }^{* *}$ Denotes coefficient significance at $1 \%$ level. ${ }^{* *}$ Denotes coefficient significance at $5 \%$ level.

benchmark, as large as those on tourism-related FDI. This further confirms the strong positive correlation between inbound tourism and inward FDI, that is, the enhancement of inbound tourism may have positive spillovers on inward FDI, which may create more development potential for non-tourism sectors

\section{Conclusions and Policy Proposals}

This paper examines the relationship between inbound tourism and inward FDI in the framework of FDI determination. In contrast to previous literature, we have not only confirmed the positive correlation between inbound tourism and tourism-related FDI, but also found that the improvement of inbound tourism exhibits positive spillovers of FDI beyond tourism-related sectors. The results indicate that FDI in other industries needs to be included, while discussing the impacts of tourism enhancement. This means that previous studies have underestimated the policy effects of enhanced tourism, since they only focus on the 
relationship between inbound tourism and tourism-related FDI. In addition, the empirical results also imply that the two policies of inbound tourism improvement and inward FDI promotion may form a virtuous cycle of interactive effects, as in the case of China.

Our analysis indicates a beneficial interaction between inward FDI and inbound arrivals to China. Specifically, tourism improvement may lure more FDI into non-tourism sectors. Additionally, the robustness of favorable interactions between tourism and FDI is confirmed under different model specifications. Thus, we can find that the two policies of inbound tourism improvement and inward FDI promotion are complementary, and that one policy amplifies the effectiveness of the other. The results are of great significance for policy making and evaluation. Since the two policies are usually formulated, implemented and evaluated independently under different government departments, policy coordination between inbound tourism and FDI should be recommended to achieve economic growth target against a background of declining global economies. In addition, the correlation degree between inbound tourism and inward FDI can be used as a reference index to evaluate whether the coordination of these two policies is effective.

The current research has some limitations. One further study is to explore whether the interactions between inbound tourism and FDI can be observed factors in other countries. If so, another potential research is to figure out the factors influence the interactions with panel data. The degree of inter action may vary with country's tourism resources. We should cover additional data on bilateral FDI and tourism in more countries to better compare cross-country differences in the extent to which policy affects each other and to make clear the conditions under which the correlation between tourism and FDI can be strengthened, which is beyond the scope of this paper.

\section{References}

[1] Wu, W.Z. and Yang, H.H. (2008) Influence Factors for the Tendency of Foreign Capital into Chinese Tourism Sector. International Economics and Trade Research, 24, 73-77.

[2] Katircioglu, S. (2011) The Bounds Test to the Level Relationship and Causality between Foreign Direct Investment and International Tourism: The Case of Turkey. $E$ + M Ekonomie a Management, 1, 6-13.

[3] Samimi, A.J., Sadeghi, S. and Sadeghi, S. (2013) The Relationship between Foreign Direct Investment and Tourism Development: Evidence from Developing Countries. Institutions and Economies, 5, 59-68.

[4] Selvanathan, S., Selvanathan, E.A. and Viswanathan, B. (2012) Causality between Foreign Direct Investment and Tourism: Empirical Evidence from India. Tourism Analysis, 17, 91-98. https://doi.org/10.3727/108354212X13330406124296

[5] Tang, S., Selvanathan, E.A. and Selvanathan, S. (2007) The Relationship between Foreign Direct Investment and Tourism: Empirical Evidence from China. Tourism Economics, 13, 25-39. https://doi.org/10.5367/000000007779784498

[6] Gao, M. (2011) Scale of Inbound Tourism and FDI Dependence. Tourism Forum, 4, 44-50. 
[7] Jackson, J. (2006) Developing Regional Tourism in China: The Potential for Activating Business Clusters in a Socialist Market Economy. Tourism Management, 27, 695-706. https://doi.org/10.1016/j.tourman.2005.02.007

[8] Tai, P. (2014) A Sustainable Development Strategy for the Use of Foreign Direct Investment in China Tourism Industry. Tourism Tribune, 29, 89-96.

[9] Tomohara, A. (2015) Japan's Tourism-Led Foreign Direct Investment Inflows: An Empirical Study. Economic Modelling, 38, 1-7.

[10] Arellano, M. and Bover, O. (1995) Another Look at the Instrumental Variable Estimation of Error-Components Models. Journal of Econometrics, 68, 29-51. https://doi.org/10.1016/0304-4076(94)01642-D

[11] Blundell, R. and Bond, S. (1998) Initial Conditions and Moment Restrictions in Dynamic Panel Data Models. Journal of Econometrics, 87, 115-143. https://doi.org/10.1016/S0304-4076(98)00009-8

[12] Windmeijer, F. (2005) A Finite Sample Correction for the Variance of Linear Efficient Two-Step GMM Estimators. Journal of Econometrics, 126, 25-51. https://doi.org/10.1016/j.jeconom.2004.02.005

[13] Blonigen, B.A. and Piger, J. (2014) Determinants of Foreign Direct Investment. Canadian Journal of Economics/Revue canadienne d'économique, 47, 775-812. https://doi.org/10.1111/caje.12091

[14] Markusen, J.R. (1997) Trade versus Investment Liberalization. NBER Working Paper No. 6231. https://doi.org/10.3386/w6231

[15] Markusen, J.R., Venables, A.J., Konan, D.E. and Zhang, K.H. (1996) A United Treatment of Horizontal Direct Investment, Vertical Direct Investment, and the $\mathrm{Pa}$ ttern of Trade in Goods and Services. NBER Working Paper No. 5696.

[16] Carr, D.L., Markusen, J.R. and Maskus, K.E. (2001) Estimating the Knowledge-Capital Model of the Multinational Enterprise. The American Economic Review, 91, 693-708. https://doi.org/10.1257/aer.91.3.693

[17] Carr, D.L., Markusen, J.R. and Maskus, K.E. (2003) Estimating the KnowledgeCapital Model of the Multinational Enterprise: Reply. American Economic Review, 93, 995-1001. https://doi.org/10.1257/000282803322157223

\section{Submit or recommend next manuscript to SCIRP and we will provide best service for you:}

Accepting pre-submission inquiries through Email, Facebook, LinkedIn, Twitter, etc. A wide selection of journals (inclusive of 9 subjects, more than 200 journals) Providing 24-hour high-quality service User-friendly online submission system Fair and swift peer-review system Efficient typesetting and proofreading procedure Display of the result of downloads and visits, as well as the number of cited articles Maximum dissemination of your research work

Submit your manuscript at: http://papersubmission.scirp.org/ Or contact me@scirp.org 